\title{
Assessment of Specific Yield and Storage Capacity of Groundwater using Borehole Log
}

\author{
M. R. Hasan ${ }^{1,3} \quad$ I. Matin 2 M. G. Mostafa ${ }^{3 *}$ \\ 1.Department of Civil Engineering, Bangladesh Army University of Engineering and Technology, Qadirabad \\ Cantonment, Natore-6431, Bangladesh \\ 2.Department of Civil Engineering, Rajshahi University of Engineering and Technology, Rajshahi 6204 , \\ Bangladesh \\ 3.Institute of Environmental Science, University of Rajshahi, Rajshahi 6205, Bangladesh
}

\begin{abstract}
The study aimed at evaluating the specific yield and storage capacity of groundwater in Chapai Nawabganj District of Bangladesh using borehole log data. The boring log samples from different layers were collected from each Upazila (administrative area) of the District. The specific yield of each Upazila was determined by the CooperJacob method using Math lab software and storage of groundwater was then ascertained by a mathematical formula. The specific yield of the five Upazilas was determined and the values were found around 10 (\%) which indicates good permeability of the areas, except Bholahat Upazila. The results illustrate that Nachole Upazila has a large storage volume, i.e., 49,305 Hec-m, but the other Upazilas have a storage capacity between 8000 to $18000 \mathrm{Hec}-$ $\mathrm{m}$. The storage capacity of the five Upazilas followed the order: Nachole $>$ Nawabganj $>$ Shibganj $>$ Gomastapur $>$ Bholahat. The highest number of DTWs at Nachole Upazila extracted 8848 Hec-m indicating excessive extraction concerning sustainable water management. A well-planned water resource management would have to be taken to achieve sustainable use of groundwater for irrigation aiming to achieve food security as well as an ecologically friendly environment.
\end{abstract}

Keywords: Borehole, groundwater, storage, specific yield, storage capacity

DOI: $10.7176 / \mathrm{JEES} / 10-8-02$

Publication date:August $31^{\text {st }} 2020$

\section{Introduction}

Groundwater aquifer is an important natural resource for domestic, industrial, commercial, and irrigation purpose in Bangladesh. About $96 \%$ of the total population in Bangladesh has access to drinking water from groundwater resources. It is the single largest source of domestic and irrigation water supplies in most of the developing countries (Helal et al., 2011). Bangladesh is the land of rivers, many rivers crossed over it. Agriculture in Bangladesh depends on irrigation during the dry eight months starting from November ending in June. But, the surface water is not enough to meet irrigation water demand in the dry season. In general, the term groundwater or subsurface water refers to the water that occurs below the surface of the earth. Groundwater-fed irrigation is conducted to cultivate high-yielding rice during the dry season in South Asia, where India and Bangladesh represent the world second and fourth biggest rice-producing nations respectably (Hasan et al., 2018; Scott and Sharma, 2009). In the past three decades, excessive installation of rural groundwater supplies through tube wells has led to increasing contamination in the groundwater of Bangladesh (Mostafa et al., 2017). A report showed that irrigation is responsible for more than $65 \%$ of all freshwater withdrawals and one-quarter of the world's irrigated land is supplied by groundwater and $75 \%$ of these lands are located in Asia. Before 1970, irrigation water in Bangladesh was mainly dependent on surface water and monsoon rainfall. But last two decades, about $79.1 \%$ of agriculture lands are supplied water for Boro rice from groundwater (Rahman and Mahbub, 2012).

In Bangladesh, total annual (2004-2005) irrigation water use was estimated to be $246 \mathrm{~km}^{3}$ of which $18 \mathrm{~km}^{3}$ comes from groundwater (Siebert et al., 2010) via a range of pumping technologies. Groundwater is a vital source of water supply in Bangladesh. Bangladesh is almost entirely underlain by water-bearing formations at depths varying from zero to 12 meter below the ground surface. Most of the area of Bangladesh possesses deltaic formation of alluvial deposits. The land elevation is about 61 meter in the Northern plains and 15 meter in the middle plains and a few meters above mean sea level at the coastal plains. The topographical and hydrological conditions are having the soil strata remaining below the critical level of the water table elsewhere in Bangladesh (Banglapedia, 2006). But all strata do not contain sufficient water that can be pumped or may not give water for a long time. Three main rivers, the Padma, Jamuna, and Meghna with their network of tributaries pass through the deltaic region of Bangladesh filling the lands with alluvial deposits and other unconsolidated material such as sand and gravel which the river carries with them draining the Himalayan ranges. The thickness of these stratified alluviums in the entire area exceeds 30 meters. The continuous layers although containing occasional lenses of clay occur at a depth varying from $15 \mathrm{~m}$ to $90 \mathrm{~m}$. Gravel is frequently marked with fine to medium sand. Coarse sand is found rarely and is thin layers. Within the stratified aquifer occurrence of medium sand is the maximum (BMDA, 2006). 
About $30 \%$ of the earth's freshwater stores in the underground aquifer, is the main source of domestic and irrigation purposes use in most of the developing countries (Hasan et. al., 2013; Encyclopedia of Earth. Website). Exploitation or over the withdrawal of groundwater resources imposes stress on groundwater regime distorting the aquifer recharge-withdrawal equilibrium and as a result, a continuous decline in water table may occur causing much adverse surface and subsurface environmental effect (Chen et al., 2003; Gehman et al., 2006; Garg, 1976). A study report on groundwater depletion in Barind Tract of Bangladesh illustrated that the maximum water table depletion was found between February to May and elevated water tables were found throughout July-October during 2007- 2016 due to monsoon and post-monsoon recharge of groundwater. A report showed that that the groundwater level (0.1-0.5 m/year) was declining to indicate a reduction in aquifer storage for unsustainable groundwater abstraction for both irrigation and urban water supplies (Hasan et al., 2013; Shamsudduha et al., 2011; BMDA, 2006). In India, Punjab and Haryana are experiencing a very rapid decline in water tables and threaten future food security in the country (Srivastava, 2017). Water demand is increasing rapidly due to population growth and socio-economic development in recent times, needed to take a holistic approach in this sector. The study aimed to assess the specific yield and storage capacity of groundwater of Chapai Nawabganj District in Bangladesh. It originates from three main sources, namely, agriculture, industrial uses, and human consumption. The booming demand for crop production, in particular, is increasing the demand for water. Effective water resource management is critical to facilitating sustainable water use.

\section{Materials and Methods}

\subsection{Study area}

Barind, the name derived from a Persian word called Barinda means, land of small hillocks. Since the same typical hillock features are evident in this region the tract is named as Barind. Many other characteristics influenced this type of land, one of the salient features of this tract in its non-flooding characteristics. It was assumed that the region is not feasible for groundwater development due to the non-availability of the required aquifer. Also, the availability of surface water for irrigation purposes in the Barind tract is very limited. However, this tract has got the great potentialities in adding to a great extent to the granary of the country. Barind area is located in the northwestern part of Bangladesh consisted of most parts of six Districts, namely Chapai Nawabganj, Rajshahi, Naogaon, Joypurhat, Bogra, Dinajpur, and Rangpur. The area is situated in 24-23' to 25-15 N and 88-02 to 88-57 E. The groundwater overexploitation has caused the water table depletion to the extent of not getting fully replenished by the rainfall recharge. The irrigated water exploration in the area is increasing day by day, eventually, the groundwater aquifer may be exhausted that will have a certain impact on the environment. Considering the Barind area and its irrigation project, the study has confined at a specific part, i.e., Chapai Nawabganj District of the Barind Irrigation Project. The District consists of five Upazilas, namely Nawabganj, Shibganj, Nachole, Gomastapur, and Bholahat and it lies under the Barind tract and has an area of $1744.33 \mathrm{~km}^{2}$. The main rivers of the District are the Ganges and Mahanadi. In Nawabganj District, Shibganj is the largest (525.43 sq km) Upazilas occupied $30.86 \%$ of the total area of the District, and Bholahat is the smallest (123.52 sq km) Upazilas of the District. It is bounded by the Indian state, West Bengal and Bangladesh on the north-south and west, and Rajshahi and Naogaon District on the east. The District is comprised of Barind tract, Diara, and Char lands geographical map of the District is shown in (Figure 2).

\subsection{Procedure of Data Analysis}

The secondary data were collected from BMDA office, and analyzed using software and figures were drawn using the following steps:

i. Microsoft Excel software was used to analyze ten years of groundwater data to get the average fluctuation of individual Upazila

ii. The specific yield of each Upazila was determined by the Cooper-Jacob method using Math lab software 


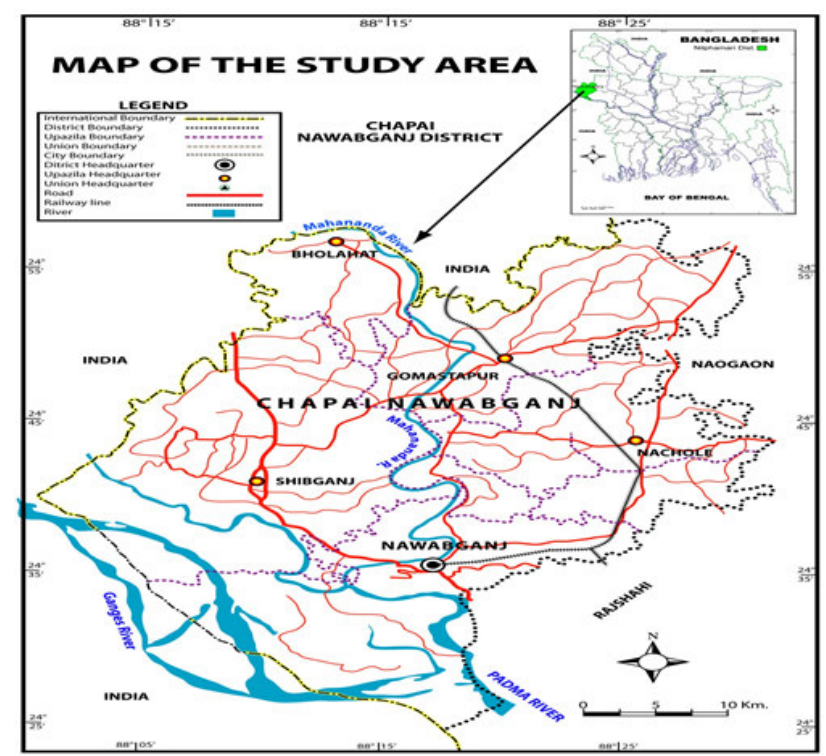

Figure 1. Sampling location map of Chapai Nawabganj District, inset map of Bangladesh

Storage of groundwater $=\mathrm{Sy} \times \mathrm{f} \times \mathrm{a}$

Where, $\mathrm{Sy}=$ Specific Yield, $\mathrm{f}=$ Fluctuation of water table, $\mathrm{a}=$ Area of respective Upazila

iv.

Groundwater withdrawal was determined as follows:

No. of deep tubewells (DTWs) capacity of DTWs running hour of each DTW per year

\subsection{Boring log data sample Collection}

A total of five boring log samples were collected from five Upazilas of Chapai Nawabganj District. The boring log samples of different layers were collected from each Upazila and the sampling locations were: (a) Upazila: Nawabganj, Union: Jhilim, Mouza: Chattigram, J.L. No. 83, Plot No. 277. (b) Upazila: Shibgang, Union: Pukuria, Mouza: Devigonj, J.L. No. 31, Plot No. 954. (c) Upazila: Nachole, Union: Fatepur, Mouza: Takahara, J.L No. 88, plot No. 572. (d) Upazila: Gomastapur, Union: Balie, Mouza: Kalinagar J.L. No. 133, Plot No. 248. (e) Upazila: Bholahat, Union: Gohalbari, Mouza: Gohalbari, J.L No. 21, Plot No. 7263.

\subsection{Sieve Analysis}

A sieve analysis is a commonly used procedure (Civil Engineering) to assess the particle size distribution (also called gradation) of a granular material. This method covers the determination of the particle size distribution of fine and coarse aggregates by sieving. A weighed sample of dry aggregates is separated through a series of sieves of progressively smaller openings for determination of particle size distribution in the test. This method was used primarily to determine the grading of materials proposed for use as aggregates or being used as aggregates.

\section{Results and Discussion}

3.1 Boring Log soil formation of Nawabganj Chapai District

The Barind Tract is an uplifted block that occurs as horst along the pre-existing line of crustal weakness. Clay thickness varies from $4 \mathrm{~m}$ in the southwest to over $35 \mathrm{~m}$ in the north-west (BMDA, 2006). The elevation of the area varies from 9m to 47m PWD (Public Works Department). 


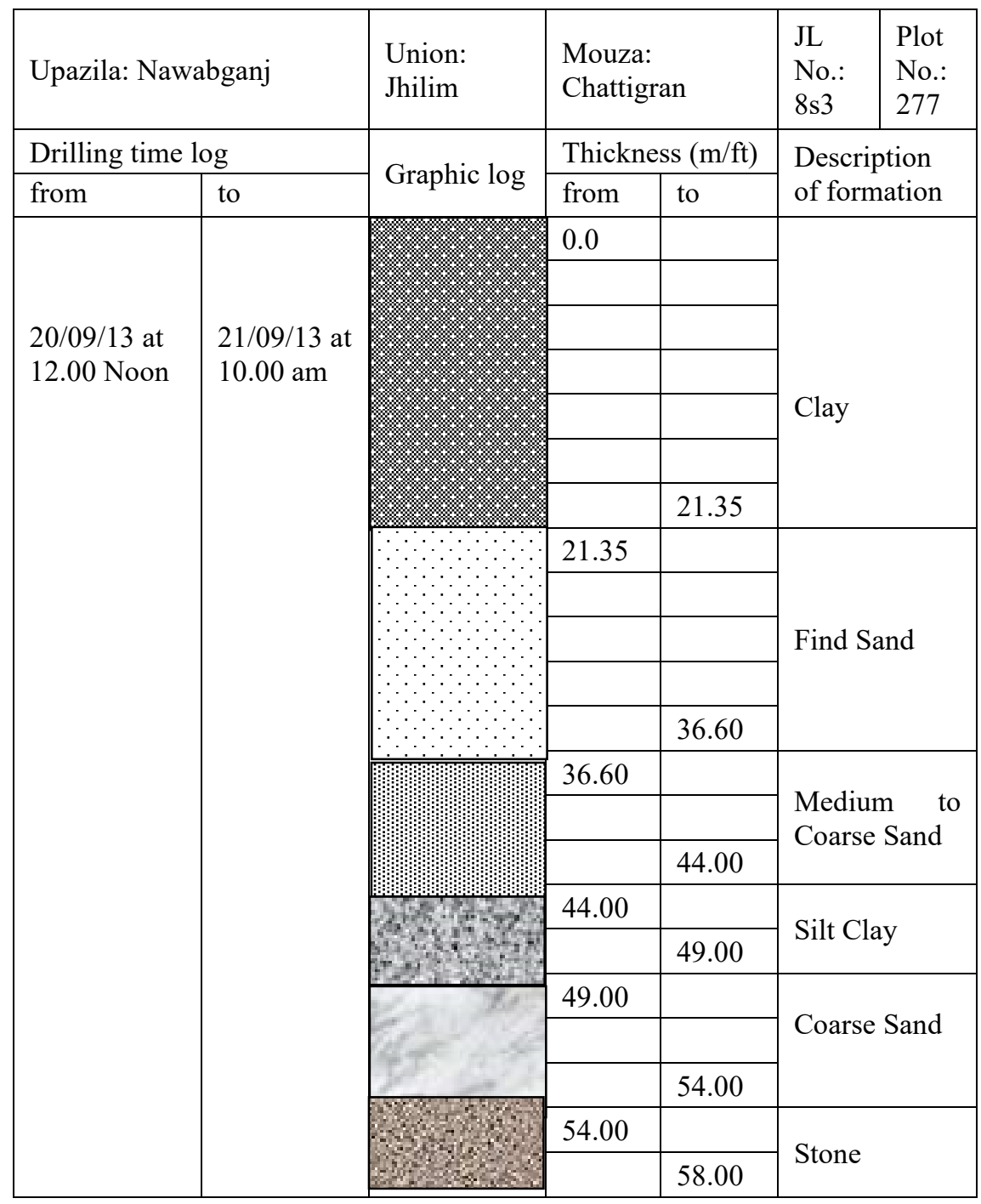

Figure 2. Boring Log Data for Nawabganj Upazila

The boreholes were drilled in 2013 by Barind Multipurpose Development Authority (BMDA) and collected soil samples from the site. Available log data from these boreholes were about 38 to $58.00 \mathrm{~m}$ from the ground surface in the study area. The different types of soil formation of five Upazilas in Chapai Nawabganj District are shown in Figure $2-6$. All the five boreholes log are very similar and the Figures of the boring log showed that a stone layer at the bottom of the bore log, immediate above of this unit is consisting of coarse sand. The silt clay, medium to coarse and fine sand were found, respectively above the slit clay. Finally, the clay made up of various additional confining units. 


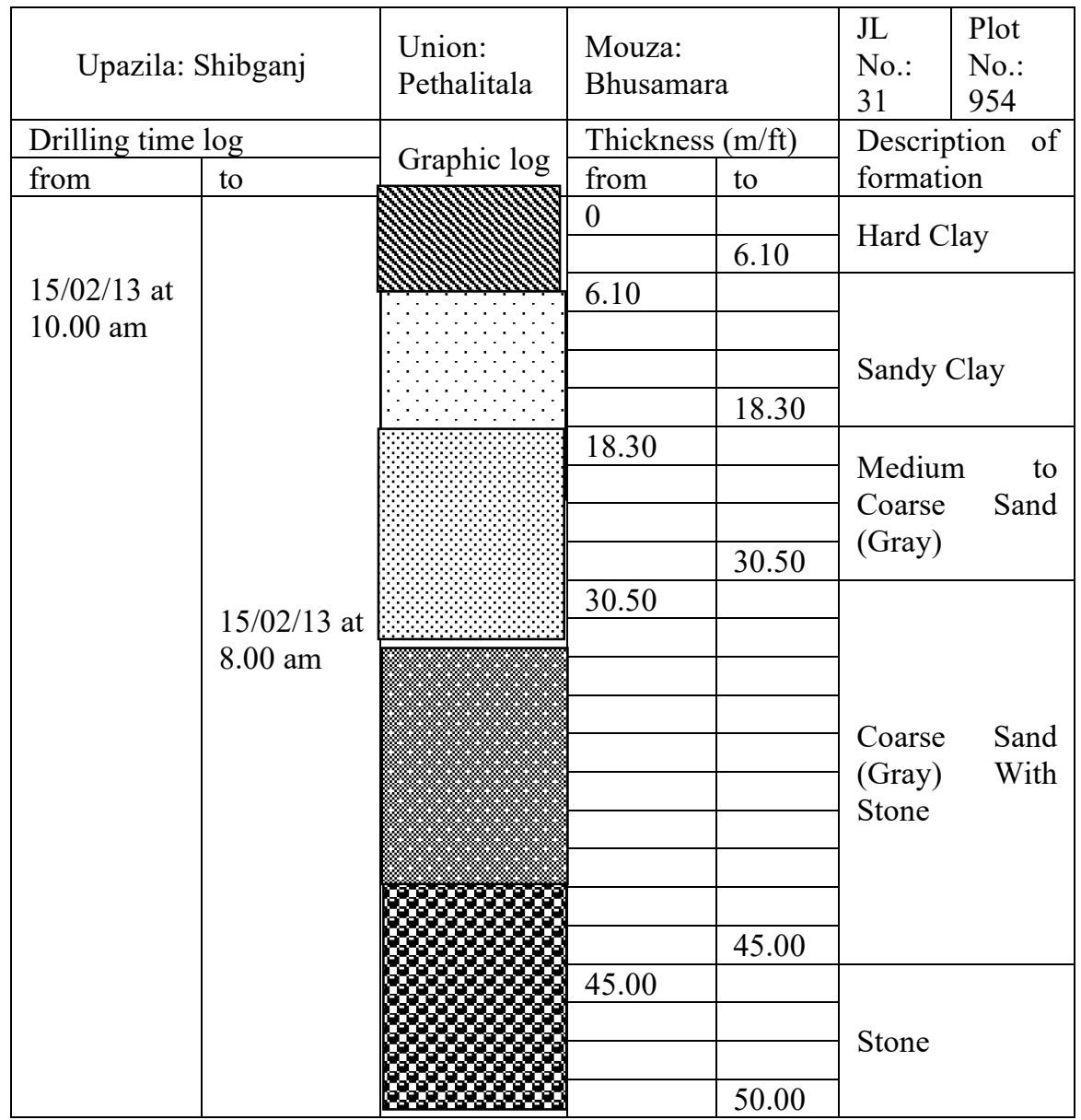

Figure 3. Boring Log Data for Shibganj Upazila

The highest thickness of clay layer $27.45 \mathrm{~m}$ was found in Chapai Nawabganj District at Nachole Upazila (Figure 4) and the lowest thickness of hard clay layer $12.20 \mathrm{~m}$ was found at the at Bholahat Upazila (Figure 6). The thickness of the clay layer was $21.35 \mathrm{~m}$, fine sand found from 21.35 to $36.60 \mathrm{~m}$ below the surface medium to coarse sand and silt clay found $36.60 \mathrm{~m}$ to $44.00 \mathrm{~m}$ and $44.00 \mathrm{~m}$ to $49.00 \mathrm{~m}$ respectively medium to coarse sand appears from $49.00 \mathrm{~m}$ to $54 \mathrm{~m}$ (Figure 2). 


\begin{tabular}{|c|c|c|c|c|c|c|}
\hline \multicolumn{2}{|c|}{ Upazila: Nachole } & $\begin{array}{l}\text { Union: } \\
\text { Fatepur }\end{array}$ & \multicolumn{2}{|c|}{$\begin{array}{l}\text { Mouza: } \\
\text { Takahara }\end{array}$} & $\begin{array}{l}\text { JL } \\
\text { No.: } \\
88\end{array}$ & $\begin{array}{l}\text { Plot } \\
\text { No.: } \\
572\end{array}$ \\
\hline \multicolumn{2}{|c|}{ Drilling time log } & \multirow[t]{2}{*}{ Graphic log } & \multicolumn{2}{|c|}{ Thickness $(\mathrm{m} / \mathrm{ft})$} & \multirow{2}{*}{\multicolumn{2}{|c|}{$\begin{array}{l}\text { Description of } \\
\text { formation }\end{array}$}} \\
\hline from & to & & from & to & & \\
\hline \multirow[t]{4}{*}{$\begin{array}{l}30 / 01 / 13 \text { at } \\
12.00 \mathrm{am}\end{array}$} & \multirow[t]{4}{*}{$\begin{array}{l}31 / 01 / 13 \text { at } \\
08.00 \mathrm{am}\end{array}$} & & 0 & 27.45 & \multicolumn{2}{|c|}{ Clay (Brown) } \\
\hline & & & 27.45 & 29.00 & \multicolumn{2}{|c|}{$\begin{array}{l}\text { Fine Sand } \\
\text { (Brown) }\end{array}$} \\
\hline & & \multirow[b]{2}{*}{ 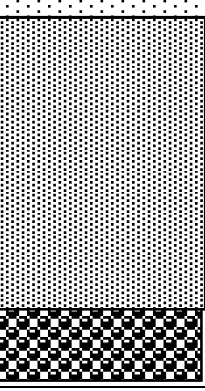 } & 29.00 & 37.00 & \multicolumn{2}{|c|}{$\begin{array}{l}\text { Medium sand } \\
\text { (Gray) }\end{array}$} \\
\hline & & & 37.00 & 38.00 & \multicolumn{2}{|c|}{ Stone } \\
\hline
\end{tabular}

Figure 4. Boring Log Data for Nachole Upazila

Figures 2- 6 show that the thickness of the clay layer is highest at Nachole Upazila borehole and it was about $27.45 \mathrm{~m}$ (Figure 4 ) and below the depth from the ground sand aquifer found with the appearance of brown and gray colored medium sand. After drilling of $57.00 \mathrm{~m}$ (Figure 2) from the ground, the stone appeared in the area. About five borehole log data of five Upazilas of Chapai Nawabganj District are analyzed and the average thickness was found $19.52 \mathrm{~m}$ (not shown in Figure). 


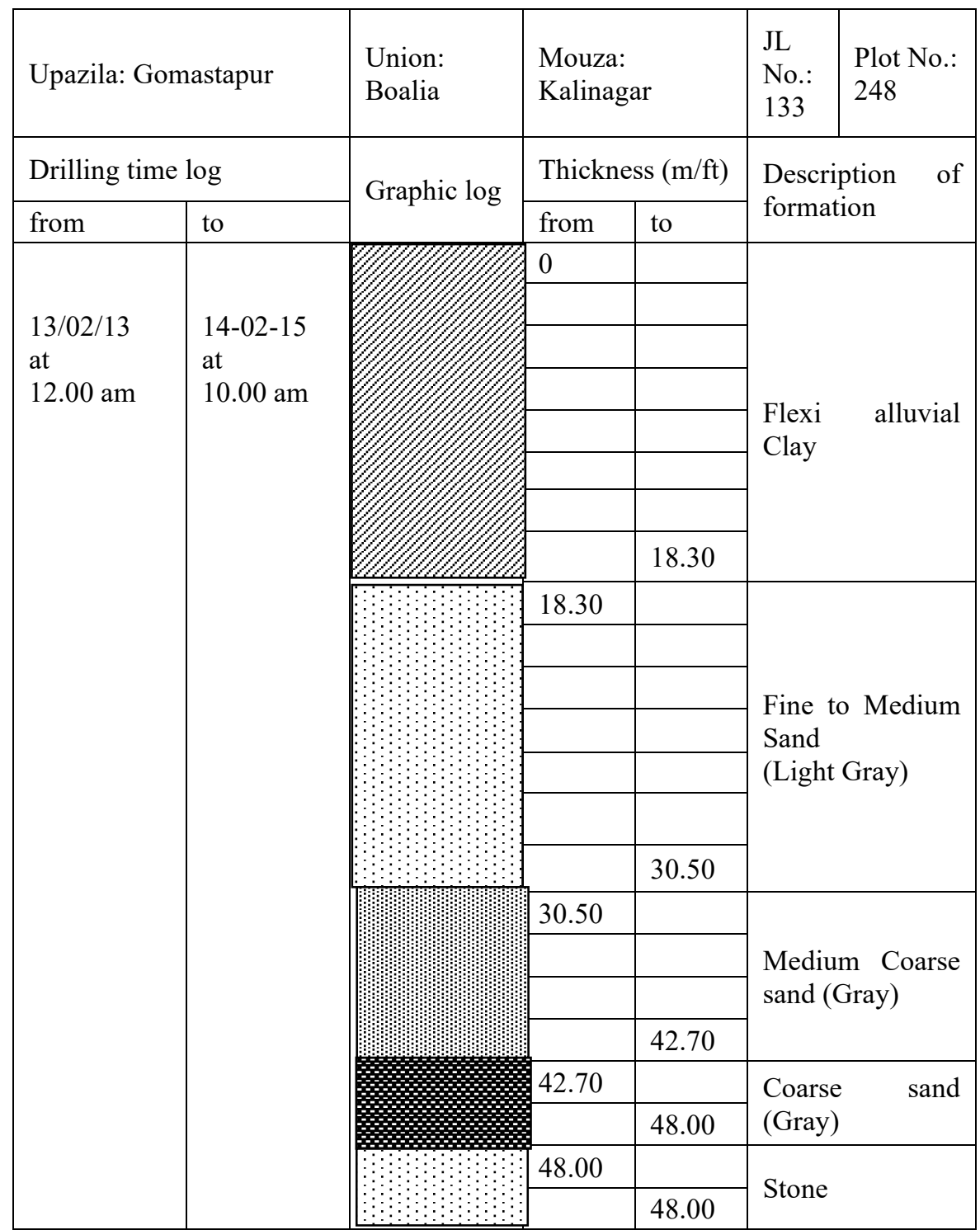

Figure 5. Boring Log Data for Gomastapur Upazila

Clay becomes sticky and clumpy when wet. It also has fine particles, only visible with a microscope. Clay soil tends to have poor drainage and it is slow to warm up. It is difficult to plant in clay soil since it hardens to a consistency nearly as hard as concrete which is very low permeability and can pass a little amount infiltration (Moench, 1993). The permeability of the clay is very low and it is termed as aquitard (BMDA 2006). 


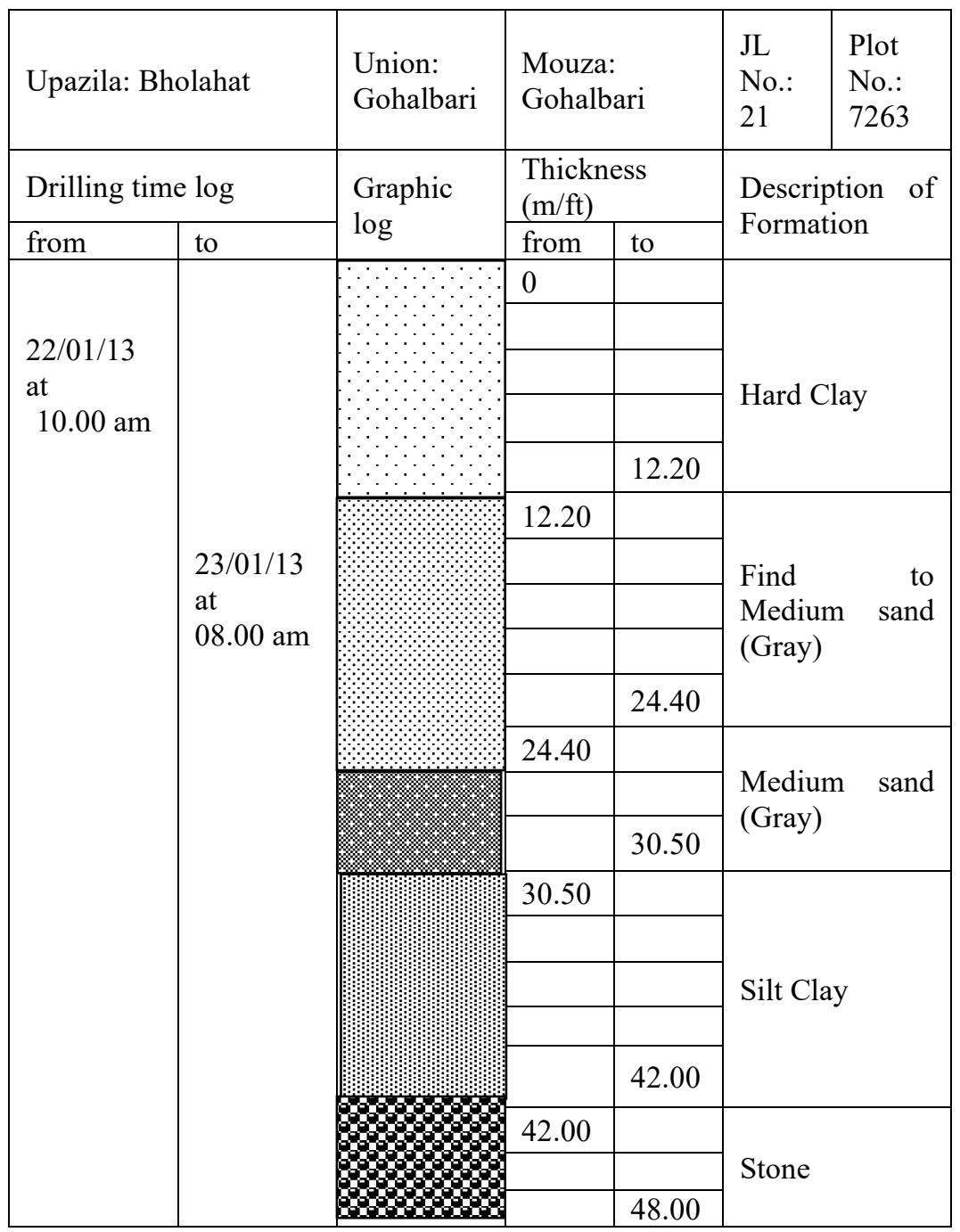

Figure 6. Boring Log Data for Bholahat Upazila.

\subsection{Determination of specific yield}

Copper-Jacob method of solution of pumping test data was obtained using the programming software Math lab (Cooper and Jacob, 1946; Birsoy and Summers, 1980). The drawdown was plotted as a function of time in the semi-logarithmic paper. The specific yield coefficient $(\Delta \mathrm{s})$ of Nawabganj Upazila was estimated from the gradient of the straight line (Figure 7) and the value was 0.983606 . The extended line to where it crossed the $\mathrm{x}$-axis that is called zero drawdowns $\left(t_{o}\right)$ and the value was 5.8. Similarly, specific yield coefficient of other Upazilas, namely Shibganj, Nachole, Bholahat, and Gomastapur were 0.993, 0.996, 0.997, and 0.997, respectively and $t_{o}$ was 8.0, $8.20,7.00$ and $7.00 \mathrm{~min}$., respectively (Table 1). The specific yield of the five Upazilas was determined using the equation mentioned in Table 1 and the values were found around $10(\%)$ which indicates good permeability of the areas, except Bholahat Upazila, where the value was $8.4(\%)$ indicating low permeability. 


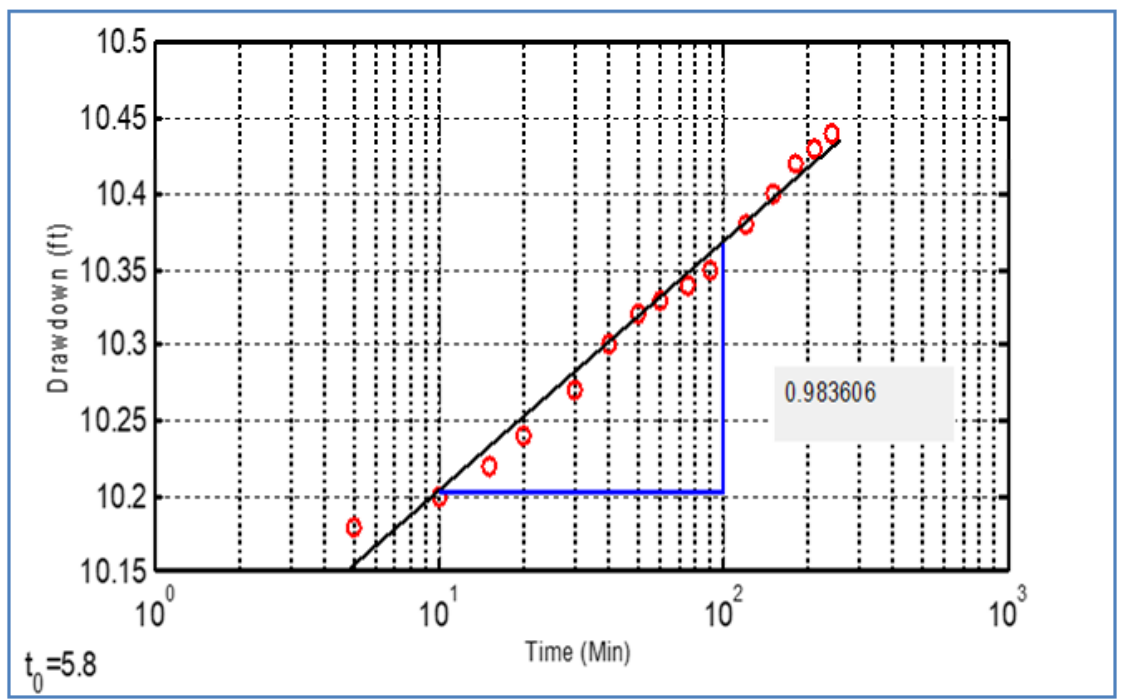

Figure 7. Copper-Jacob method of solution of pumping test data for Nawabganj Upazila

Table 1. Determination of specific yield of five Upazilas of Chapai Nawabganj District

\begin{tabular}{|l|l|l|l|l|l|l|}
\hline Upazila & $\begin{array}{l}\text { Discharge } \\
Q\left(\mathrm{ft}^{3} / \mathrm{min}\right)\end{array}$ & $\begin{array}{l}\text { Drawdown } \\
\text { difference } \\
\text { per log } \\
\text { cycle } \\
\Delta S(\mathrm{ft})\end{array}$ & $\begin{array}{l}\text { Radius of } \\
\text { influence } \\
r_{e}(\mathrm{ft})\end{array}$ & $\begin{array}{l}\text { Zero } \\
\text { Drawdown } \\
t_{0}(\mathrm{~min})\end{array}$ & $\begin{array}{l}\text { Transmissivity } \\
=2.3 Q / 4 \pi \Delta S \\
\left(\mathrm{ft}^{2} / \mathrm{min}\right)\end{array}$ & $\begin{array}{l}\text { Specific } \\
\text { Yield } \\
S_{y}=2.25 \quad t_{o} / r_{e}{ }^{2}(\%)\end{array}$ \\
\hline Nawabganj & 120 & 0.983 & 30.68 & 5.8 & 22.34 & 9.5 \\
\hline Shibganj & 120 & 0.993 & 40.41 & 8.20 & 22.12 & 10.1 \\
\hline Nachole & 120 & 0.996 & 38.53 & 8.0 & 22.05 & 10.3 \\
\hline Gomastapur & 120 & 0.997 & 34.02 & 7 & 22.03 & 10.2 \\
\hline Bholahat & 120 & 0.997 & 41.31 & 7.00 & 22.03 & 8.4 \\
\hline
\end{tabular}

3.3 Groundwater storage of five Upazilas in Chapai Nawabganj District.

Groundwater is water located below the ground surface in soil pore spaces and rock fractures. In nature, surface water and groundwater are intimately connected via the water cycle. Surface water, flowing or stagnant, percolates downward through the soil and becomes part of the groundwater table (Pool and Schmidt, 1997; Nwankwor et al, 1984; Moench, 1993.

The storage capacity of the five Upazilas in Chapai Nawabganj District was estimated using the average water table fluctuation, and specific yield of groundwater. The results illustrated that Nachole Upazila has comparatively a large storage volume, i.e., 49,305 ha-m, and the other Upazilas have a storage capacity between 8000 to 18000 ha-m (Table 2). The storage capacity of the five Upazilas followed the order: Nachole $>$ Nawabganj $>$ Shibganj $>$ Gomastapur $>$ Bholahat.

\subsection{Groundwater withdrawing at five Upazilas of Chapai Nawabganj District per year}

A total of 43 deep tubewells (DTWs) at the rate of 2 cusec capacity were operated for 800 hours/year at Nawabganj Upazila and the extraction of groundwater/year of the Upazila was 3471 ha-m (Table 3). The highest number of DTWs was installed at Nachole Upazila and the extracted amount was 8848 ha-m indicating excessive extraction concerning sustainable water management. There was no report of land subsidence in the study area till October 2014 but, precautions would be made ahead of any incidence to be taken place. Overexploitation of groundwater has increased the possibility of deteriorating water quality in the area (Hasan et al., 2018). The introduction of contaminants into groundwater aquifer through human or natural activities deteriorated the water quality. Despite the overdraft of groundwater, arsenic was not detected in any DTW water samples collected in the study. The sustainability of groundwater ultimately depends on balancing withdrawals with rates of recharge (Howle et al., 2003). 
Table 2. Estimated storage of groundwater of five Upazilas of Chapai Nawabganj District

\begin{tabular}{|l|l|l|l|l|l|}
\hline SL No. & Upazila & $\begin{array}{l}\text { Specific yield } \\
S_{y}\end{array}$ & $\begin{array}{l}\text { Area } \\
(\text { ha. }) a\end{array}$ & $\begin{array}{l}\text { Average fluctuation } \\
\text { of G.W. }(\mathrm{m}) f\end{array}$ & $\begin{array}{l}\text { Storage of G.W. (ha- } \\
\mathrm{m}) S y \times a \times f\end{array}$ \\
\hline 1 & Nawabganj & 0.095 & 45178 & 4.3 & 18455.21 \\
\hline 2 & Shibganj & 0.101 & 31813 & 4.7 & 15101.63 \\
\hline 3 & Nachole & 0.102 & 52542 & 9.2 & 49305.41 \\
\hline 4 & Gomastapur & 0.103 & 28367 & 3.9 & 11395.02 \\
\hline 5 & 0.084 & 12353 & 8.4 & 8716.277 \\
\hline \multicolumn{5}{|l|}{ Botal Storage of groundwater } \\
\hline
\end{tabular}

Table 3. Volume of water extracted per year in five Upazilas of Chapai Nawabganj District

\begin{tabular}{|c|c|c|c|c|}
\hline SL. No. & Name of Upazila & DTWs & Vol $^{\mathrm{m}}$ water Extracted. (ha-m) & Total Vol ${ }^{\mathrm{m}}$ extracted (ha-m) \\
\hline 1 & Nawabganj & 43 & 3471 & \multirow{5}{*}{26822} \\
\hline 2 & Shibganj & 243 & 3960 & \\
\hline 3 & Nachole & 543 & 8848 & \\
\hline 4 & Gomostapur & 401 & 6534 & \\
\hline 5 & Bholahat & 246 & 4009 & \\
\hline
\end{tabular}

Some of the urgent steps are to be needed to maintain sustainable water resource management and development of irrigated agriculture projects in the area and these are as follows:

- Campaign to promote water harvesting including rainwater

- Establish projects to promote the dependency on surface water for irrigation water supply

- Prevent the unsustainable exploitation of the aquifers.

- Store water in large reservoirs or cannels during monsoon and use a substantial amount in the dry season.

- Ensure efficiency, economy, and equity in water use through cooperative management of water resources in command areas.

Thus, peoples' participation in water harvesting, conservation, and efficient use will foster both sustainable food and irrigation water security.

\section{Conclusions}

The results showed that the highest thickness of clay layer $27.45 \mathrm{~m}$ was found in Chapai Nawabganj District at Nachole Upazila and the lowest thickness of hard clay layer $12.20 \mathrm{~m}$ was found at the at Bholahat Upazila. The specific yield of the five Upazilas was determined and the values were found around $10(\%)$, which indicates good permeability of the areas, except Bholahat Upazila.

The storage capacity of the five Upazilas in Chapai Nawabganj District showed that Nachole Upazila has a comparatively large storage volume of 49,305 ha-m, and the other Upazilas have a storage capacity between 8000 to 18000 ha-m. The storage capacity of the five Upazilas followed the order: Nachole $>$ Nawabganj $>$ Shibganj $>$ Gomastapur $>$ Bholahat. A total of 43 DTWs at the rate of 2 cusec capacity were operated for 800 hours/year at Nawabganj Upazila and the extraction of groundwater/year of the Upazila was 3471 Hec-m. The highest number of DTWs was installed at Nachole Upazila and the extracted amount was 8848 Hec$\mathrm{m}$ indicating excessive extraction concerning sustainable water management. The groundwater management for sustainable irrigation and crop production in the region is imperative. A well-planned water resource management would have to be taken to achieve sustainable use of groundwater for irrigation aiming to achieve food security as well as an ecologically friendly environment. It is also imperative to follow the best irrigation management practices and climate change adaptation techniques for sustainable use of groundwater and environmentallyfriendly.

\section{References}

Banglapedia: Barind track, National Encyclopedia of Bangladesh, 2013. Internet website: www.banglapedia.org. (Last visit: 11-8-2019).

Birsoy, Y.K. and W.K. Summers, 1980. Determination of aquifer parameters from step tests and intermittent pumping, Ground Water, vol. 18, no. 2, pp. 137-146.

BMDA, 2006. "Borandro Authority Past-Present," BMDA Rajshahi, p. 35.

Chen, X. H., J. Goeke, J. F. Ayers, and S. Summerside (2003), Observation well network design for pumping tests in unconfined aquifers, J. Am. Water Resour. Assoc., 39(1), 17- 32, doi:10.1111/j.1752-1688.2003.tb01558.x.

Cooper, H.H. and C.E. Jacob, 1946. A generalized graphical method for evaluating formation constants and summarizing well field history, Am. Geophys. Union Trans., vol. 27, pp. 526-534.

Garg, S. K., 1976. Irrigation Engineering and Hydraulic Structures. 2-B, Nath Market, Delhi-110006.

Gehman, C., D. L. Harry, and W. E. Sanford (2006), Measuring groundwater storage change in an unconfined 
alluvial aquifer using temporal gravity surveys, paper presented at 19th Annual Symposium on the Application of Geophysics to Engineering and Environmental Problems, Soc. of Explor. Geophys., Seattle, Wash., 2 - 6 April.

Hasan, M.R., Mostafa, M.G. and Matin, I. (2013). Effect of rainfall on groundwater level fluctuations in Chapai Nawabganj District. International Journal of Engineering Research \& Technology (IJERT), 2(4).

Hasan, MR., Mostafa, M.G., Nafiur Rahman, Md. Saiful Islam and Md. Moynul Islam (2018). Groundwater Depletion and its Sustainable Management in Barind Tract of Bangladesh. Res. J. Environ. Sci., 12 (5), $247-$ 255.

Helal Uddin, S.M., Mostafa, M.G. and Haque, A.B.M.H. (2011). Evaluation of groundwater quality and its suitability for drinking purpose in Rajshahi City, Bangladesh. Water Science and Technology: Water Supply, 11(5), 545-559.

Howle, J. F., S. P. Phillips, R. P. Denlinger, and L. F. Metzger (2003), Determination of specific yield and watertable changes using temporal microgravity surveys collected during the second injection, storage, and recovery test at Lancaster, Antelope Valley, California, November 1996 through April 1997, U.S. Geol. Surv. Water Resour. Invest. Rep. , 03-4019, pp. 1-28.

Moench, A. F. (1993), Computation of type curves for flow to partially penetrating wells in water-table aquifers, Ground Water, 31(6), 966-971, doi:10.1111/j.1745-6584.1993.tb00870.x.

Mostafa. M.G., Helal Uddin S.M. and Haque A.B.M. (2017). Assessment of hydro-geochemistry and groundwater quality of Rajshahi City in Bangladesh. Appl Water Sci., 7 (8). DOI 10.1007/s13201-017-0629-y

Nwankwor, G. I., J. A. Cherry, and R. W. Gilham (1984), A comparative study of specific yield determinations for a shallow sand aquifer, Ground Water, 22(6), 764- 772, doi:10.1111/j.1745-6584.1984.tb01445.x.

Pool, D. R., and Schmidt, W (1997), Measurement of ground-water storage change and specific yield using the temporal-gravity method near Rillito Creek, Tucson, Arizona, U.S. Geol. Surv. Water Resour. Invest. Rep., 97-4125.

Rahman M. M., Mahbub A. Q. M. 2012. Groundwater Depletion with Expansion of Irrigation in Barind Tract: A Case Study of Tanore Upazila. Journal of Water Resource and Protection 4:567-575. DOI: 10.4236/jwarp.2012.48066.

Scott CA, Sharma B, 2009. Energy supply and the expansion of groundwater irrigation in the Indus-Ganges Basin. Intl J River Basin Mange 7: 1-6.

Shamsudduha, M., Taylor, R. G., Ahmed, K. M. and Zahid, A., 2011. "The Impact of Intensive Groundwater Abstraction on Recharge to a Shallow Regional Aquifer System: Evi-dence from Bangladesh," Hydrogeology Journal, Vol. 19, No. 4, pp. 901-916. doi:10.1007/s10040-011-0723-4

Siebert S., Bruke J, Faures JM, Freenken K, Hoogeveen J, Doll P, Portmann FT 2010. Groundwater use for irrigation: a global inventory. Hydrol Earth Syst Sci Discuss 7:3977-4021.

Srivastava, S.K., Ramesh Chand, Jaspal Singh, Amrit Pal Kaur, Rajni Jain, I. Kingsly and S. S. Raju (2017). Revisiting groundwater depletion and its implications on farm economics in Punjab, India. Current Science, 113 (3), 422-429.

Encyclopedia of Earth. Website url: https://en.wikipedia.org/wiki/Encyclopedia_of_Earth (last visit May 30, 2020) 